\title{
Nitrogen and Phosphorus Requirement to Soybean in High Phosphorus Soils
}

\author{
M. Jagadesh*, A. Madhavi, M. Chandini Patnaik and A. Madhavi Lata \\ Professor Jayashankar Telangana State Agricultural University, Hyderabad-500 030, India \\ *Corresponding author:
}

\section{A B S T R A C T}

\begin{tabular}{|l|}
\hline Ke y w o r d s \\
Completely \\
Randomized block \\
Design, seed yield, \\
haulm yield
\end{tabular}

A net house experiment was conducted during kharif, 2018 at Agricultural Research Institute, Rajendranagar, Hyderabad, Telangana state to know the requirement of $\mathrm{N}$ and $\mathrm{P}$ to soybean crop in high phosphorus soils. The soils employed for the experiment were sandy clay loam in texture, low in available nitrogen, high in phosphorus and high in potassium status. The experiment was conducted employing 4 levels of $\mathrm{N}(60,80,100$ and $120 \mathrm{~kg} \mathrm{~N} \mathrm{ha}^{-1}$ ) 2 levels of phosphorus (42 and $60 \mathrm{~kg} \mathrm{P}_{2} \mathrm{O}_{5} \mathrm{ha}^{-1}$ ) and with three high P soils having 69, 82 and $107 \mathrm{~kg}$ native available $\mathrm{P}_{2} \mathrm{O}_{5} \mathrm{ha}^{-1}$. Application of nitrogen @ $80 \mathrm{~kg} \mathrm{ha}^{-1}$ resulted in higher seed $\left(14.60 \mathrm{~g} \mathrm{pot}^{-1}\right)$ and haulm yield $\left(21.03 \mathrm{~g} \mathrm{pot}^{-1}\right)$ when compared with $60 \mathrm{~kg} \mathrm{~N} \mathrm{ha}^{-1}$ but it was found to be on par with the application of 100 and $120 \mathrm{~kg} \mathrm{~N}$ $\mathrm{ha}^{1}$.The significant increment in the seed yield of soybean was observed in all the three hig $\mathrm{h} \mathrm{P}$ soils with increase in nitrogen levels from 60 to $80 \mathrm{~kg} \mathrm{~N} \mathrm{ha}^{-1}$. Application of phosphorus@ @ 100\% RDP or 70\% RDP resulted in on par seed and haulm yield in all three high $\mathrm{P}$ soils. Thus reducing the level of phosphorus application from 60 to $42 \mathrm{~kg} \mathrm{P}_{2} \mathrm{O}_{5}$ ha $^{-1}$ had no significant effect on the yield of soybean. The yield achieved by application of 80 $\mathrm{kg} \mathrm{N} \mathrm{ha}^{-1}$ and $100 \% \mathrm{RDP}$ was found to be on par with the application of $100,120 \mathrm{~kg} \mathrm{~N}^{-}$ ${ }^{1}$ along with 70 or $100 \%$ RDP.

\section{Introduction}

Soybean is a major oilseed crop in the world. The crop's share in global oilseed output is estimated at over 50 percent. Soybean (Glycine $\max (\mathrm{L}$.$) Merrill) is a dual purpose$ legume crop recognized as an efficient producer of protein as well as oil. These are not only the major components in the diet of vegetarians mass but a boon to the developing countries as well. Therefore, soybean is an important crop promising great scope for elimination of dietary deficiency of protein and fat in the country. It contains about 40-42 percent protein and 20-22\% oil (Barik and Chandel, 2001). It is one of the major rainy season cash crop and its cultivation is fast spreading in India. Soybean contributes to 30$37 \%$ of India's oil seed production with 109.7 lakh ha of area, 114.9 lakh metric tonnes production and $1047 \mathrm{~kg} \mathrm{ha}^{-1}$ of average yield (www.sopa.org. 2017). In India, soybean is grown in 6.22 million hectares with total production of 8-9 million tonnes. In 
Telangana, it occupies about 2.43 lakh ha with 2.52 lakh tonnes of production and 1036 $\mathrm{kg} \mathrm{ha}^{-1}$ of average productivity (DES, 2017). The major uses of soybean are as a source of edible oil and protein rich food, as well as cattle feed. The nutrient requirement and interaction of different nutrients under high phosphorus conditions were not worked out so far in soybean track. To improve the productivity levels of soybean it is imperative to assess the nitrogen and phosphorus requirement under high $\mathrm{P}$ fertility soils to obtain the potential yield by the farmers.

\section{Materials and Methods}

A pot culture experiment with soybean crop (Var: Basara) was conducted during kharif, 2018 at Agricultural Research Institute, Hyderabad, Telangana state. Soils having high status of available phosphorus are used in this investigation. For this purpose, soils of representative surface soils $(0-15 \mathrm{~cm})$ were collected in and around Ranga Reddy district and used in the present investigation. These soils were initially tested for available $P$, using Olsen's extractant as per standard procedures to find out the status of available phosphorus in soils to conduct pot culture experiment. Based on status of available $\mathrm{P}$, bulk samples of high P soils were collected from those sites and were employed in the present investigation. Physical, Physicochemical and chemical properties of soils employed for pot culture study were estimated by following standard procedures and presented in table1.

Three phosphorus accumulated soils, S$1\left(69 \mathrm{kgP}_{2} \mathrm{O}_{5} \mathrm{ha}^{-1}\right), \mathrm{S}-2\left(82 \mathrm{kgP}_{2} \mathrm{O}_{5} \mathrm{ha}^{-1}\right)$ and $\mathrm{S}$ $3\left(107 \mathrm{kgP}_{2} \mathrm{O}_{5} \mathrm{ha}^{-1}\right)$ with two $\mathrm{P}$ levels as $\mathrm{P} 1$ (Soil test based phosphorus -70\%RDP) and P2 (RDP-100\% RDP) along with 4 levels of nitrogen $\left(60,80,100\right.$ and $\left.120 \mathrm{~N} \mathrm{ha}^{-1}\right)$ were selected for pot culture study with 3 replications. The collected soils after processing were filled in pots of $5 \mathrm{~kg}$ capacity and pot culture experiment was conducted with soybean as test crop (Var: Basara). Recommended doses of fertilizers (60:60:40 $\mathrm{kg}$ NPK ha ${ }^{-1}$ ) were applied during crop growth period and all package of practices were followed during crop growth period. The crop was raised till maturity and yield was recorded at harvest.

\section{Results and Discussion}

Effect of different doses of $\mathrm{N}$ and $\mathrm{P}$ levels on seed and haulm yield of soybean was presented in table 2 and 3.Application of different levels of nitrogen fertilizer to soybean crop in high $\mathrm{P}$ soils significantly influenced the soybean seed yield. It was found that increasing the $\mathrm{N}$ application from 60 to $80 \mathrm{~kg} \mathrm{ha}^{-1}$ enhanced the soybean seed yield by $12.7 \%$ significantly from 12.96 to $14.60 \mathrm{~g} \mathrm{pot}^{-1}$. Subsequent enhancement of N application from 80 to $120 \mathrm{~kg} \mathrm{ha}^{-1}$ to soybean crop did not affect the yield of soybean seed significantly in these high $\mathrm{P}$ soils. The overall yield of soybean seed at different levels of $\mathrm{N}$ application was in range of 12.96 to $15.18 \mathrm{~g}$ pot $^{-1}$ with mean of $14.41 \mathrm{~g} \mathrm{pot}^{-1}$.Application of $\mathrm{P}$ fertilizer to soybean crop in high $\mathrm{P}$ soils at the rate of $100 \% \operatorname{RDP}\left(60 \mathrm{~kg} \mathrm{P}_{2} \mathrm{O}_{5} \mathrm{ha}^{-1}\right)$ or $70 \% \mathrm{RDP}\left(42 \mathrm{~kg} \mathrm{P}_{2} \mathrm{O}_{5} \mathrm{ha}^{-1}\right)$ did not influence the seed yield of soybean and they were found to be statistically on par (14.56 and $14.26 \mathrm{~g}$ pot $\left.^{-1}\right)$. The interaction effect of $\mathrm{N} X \mathrm{P}$ on soybean seed yield was found to be significant. Maximum seed yield of $15.34 \mathrm{~g}$ pot $^{-1}$ was recorded due to combination of $\mathrm{N} 120+\mathrm{P} 100 \%$ RDP treatment. Similar on par yields are also observed when N 100 was in combination with either $100 \%$ RDP or $70 \%$ RDP. Different high $\mathrm{P}$ soils significantly affected the soybean seed yield. Highest seed yield of $15.56 \mathrm{~g} \mathrm{pot}^{-1}$ was observed in soil with native available $\mathrm{P}_{2} \mathrm{O}_{5}$ of $107 \mathrm{~kg} \mathrm{P}_{2} \mathrm{O}_{5}$ ha $^{-1}$ (S3) fallowed by soil with 82 (14.47 $\left.\mathrm{g} \mathrm{pot}^{-1}\right)$ and $69 \mathrm{~kg} \mathrm{P}_{2} \mathrm{O}_{5} \mathrm{ha}^{-1}\left(13.29 \mathrm{~g} \mathrm{pot}^{-1}\right)$. These 
differences in seed yield were found to be statistically significant. The interaction effect of high $\mathrm{P}$ soils and doses of $\mathrm{N}$ application was found to be significant on seed yield of soybean. In general, the combination of high $\mathrm{N}$ doses like 100 and $120 \mathrm{~kg} \mathrm{P}_{2} \mathrm{O}_{5} \mathrm{ha}^{-1}$ in very high $\mathrm{P}$ soil (107 $\mathrm{kg} \mathrm{P}_{2} \mathrm{O}_{5} \mathrm{ha}^{-1}$ ) resulted in highest soybean seed yield when compared to other combination in study. The interaction effect of high $\mathrm{P}$ soils and $\mathrm{P}$ doses applied to crop on soybean seed yield was found to be statistically significant. The interaction effect of $\mathrm{N}, \mathrm{P}$ and different high $\mathrm{P}$ soils on soybean seed yield was found to be statistically significant. It was observed that the seed yield in general was higher in very high $\mathrm{P}$ soil at high doses of $\mathrm{N}$ irrespective of $100 \%$ or $70 \%$ RDP.

Haulm yield of soybean is significantly influenced by application of different levels of nitrogen fertilizer to soybean crop in high $\mathrm{P}$ soils. The overall yield of soybean haulm at different levels of $\mathrm{N}$ application was in range of 18.42 to $22.37 \mathrm{~g} \mathrm{pot}^{-1}$ with mean of $20.93 \mathrm{~g}$ $\operatorname{pot}^{-1}$. It was found that increasing the $\mathrm{N}$ application from 60 to $80 \mathrm{~kg} \mathrm{ha}^{-1}$ enhanced the haulm yield significantly from 18.42 to $21.03 \mathrm{~g} \mathrm{pot}^{-1}$. Subsequent enhancement of $\mathrm{N}$ application from 80 to $120 \mathrm{~kg} \mathrm{ha}^{-1}$ to soybean crop did not effect the haulm yield of soybean significantly in these high $\mathrm{P}$ soils. Application of $\mathrm{P}$ fertilizer to soybean crop in high $\mathrm{P}$ soils at the rate of $100 \% \mathrm{RDP}\left(60 \mathrm{~kg} \mathrm{P}_{2} \mathrm{O}_{5} \mathrm{ha}^{-1}\right)$ or $70 \%$ RDP (42 $\mathrm{kg} \mathrm{P}_{2} \mathrm{O}_{5} \mathrm{ha}^{-1}$ ) did not influence the haulm yield of soybean and they were found to be statistically on par (21.31 and $\left.20.55 \mathrm{~g} \mathrm{pot}^{-1}\right)$. There was a significant result in the interaction effect of $\mathrm{N} \mathrm{X} \mathrm{P}$ on soybean haulm yield. Maximum haulm yield of 22.81 g pot $^{-1}$ was recorded due to combination of $\mathrm{N} 120+\mathrm{P} 100 \%$ RDP treatment. Similar on par yields are also observed when N100 was in combination with either $100 \%$ RDP or $70 \%$ RDP. Different high P soils had a significant effect on haulm yield of soybean. Highest haulm yield of $22.35 \mathrm{~g} \mathrm{pot}^{-1}$ was observed in soil with native available $\mathrm{P}_{2} \mathrm{O}_{5}$ of $107 \mathrm{~kg} \mathrm{P}_{2} \mathrm{O}_{5}$ $\mathrm{ha}^{-1}$ (S3) fallowed by soil with $82(20.85 \mathrm{~g}$ $\operatorname{pot}^{-1}$ ) and $69 \mathrm{~kg} \mathrm{P}_{2} \mathrm{O}_{5} \mathrm{ha}^{-1}\left(19.58 \mathrm{~g} \mathrm{pot}^{-1}\right)$. The interaction effect of high $\mathrm{P}$ soils and doses of $\mathrm{N}$ application was found to be significant on haulm yield of soybean. In general, the combination of high $\mathrm{N}$ doses like 100 and 120 $\mathrm{kg} \mathrm{P}_{2} \mathrm{O}_{5}$ ha $^{-1}$ in very high $\mathrm{P}$ soil $\left(107 \mathrm{~kg} \mathrm{P}_{2} \mathrm{O}_{5}\right.$ $\mathrm{ha}^{-1}$ ) resulted in highest soybean haulm yield when compared to other combination in study. The interaction effect of high $\mathrm{P}$ soils and $\mathrm{P}$ doses applied to crop on soybean haulm yield was found to be statistically significant. The interaction effect of $\mathrm{N}, \mathrm{P}$ and different high $\mathrm{P}$ soils on haulm yield of soybean was found to be statistically significant. It was observed that the haulm yield in general was higher in very high $\mathrm{P}$ soil at high doses of $\mathrm{N}$ irrespective of $100 \%$ RDP or $70 \%$ RDP.

Application of different doses of nitrogen to this high $\mathrm{P}$ soils resulted response to soybean seed yield (Table. 2). Application of N@80 $\mathrm{kg} \mathrm{N} \mathrm{ha}{ }^{-1}$ increased the soybean seed yield significantly by $12.7 \%$ over $60 \mathrm{~kg} \mathrm{~N} \mathrm{ha}^{-1}$. Further increase in dose of $\mathrm{N}$ from 80 to 120 $\mathrm{kg} \mathrm{N} \mathrm{ha}{ }^{-1}$ to soybean crop did not influence the yield of soybean seed significantly in these high $\mathrm{P}$ soils. At higher levels of nitrogen doses crop not responded to external application of nitrogen might be as a leguminous crop soybean meets their nitrogen requirement through biological nitrogen fixation. Previous research results conducted on low $\mathrm{N}$ and low to medium $\mathrm{P}$ soils resulted in seed yield response to $\mathrm{N}$ application in the range of 10-30 \% (Siddiqui et al., 2007, Abdalmoshin, 2016) when $\mathrm{N}$ was applied in the range of 0 to $100 \mathrm{~kg} \mathrm{~N} \mathrm{ha}^{-1}$.

Application of phosphorus fertilizer based on conventional soil test based $\mathrm{P}$ recommendation (30\% reduction of RDP) to high $\mathrm{P}$ soils recorded on par yields with $100 \%$ RDP (Table.2). It is noticed that the 
enhancement in seed yield of soybean was only $2 \%$ due to application of $100 \%$ recommended dose of phosphorus $(60 \mathrm{~kg}$ $\left.\mathrm{P}_{2} \mathrm{O}_{5} \mathrm{ha}^{-1}\right)$ over $70 \% \mathrm{RDP}\left(42 \mathrm{~kg} \mathrm{P}_{2} \mathrm{O}_{5} \mathrm{ha}^{-1}\right)$ to this high $\mathrm{P}$ soils. These observations clearly indicate that it is possible to reduce current RDP by $30 \%$ in high $\mathrm{P}$ soils without scarifying the yield. Application of RDP to many crops having low to medium available phosphorus was found to result in enhanced yields to the tune of 15 to $20 \%$ depending upon initial available P status (Varavipour et al., 1999; Akhtar et al., 2003; Ikeogu and Nwofia, 2013; Dhage et al., 2014).

At the same time the seed yields obtained with reduced P application (70\% RDP) below $100 \%$ RDP is also found to result in on par yield like that of $100 \%$ RDP in the high P soils. Babu et al., (2005) reported possible saving of as much as $50 \%$ of $\mathrm{P}$ from recommended dose for rice crop in high $\mathrm{P}$ soils. Reduced P application by $25-50 \%$ from the current RDP in high P soils is reported to be a possible $\mathrm{P}$ saving measure without scarifying the yields in crops for e.g., in rice, sunflower, rice-rice, rice-sunflower (Babu et al., 2005; Ramya et al., 2015, Srinivas et al., 2017). Thus the present results clearly establish once again that the $\mathrm{P}$ application can be saved in high $\mathrm{P}$ soils including the $\mathrm{P}$ loving crop like soybean.

Different high P soils having different native available phosphorus status also significantly affected the seed yield of soybean (Table. 2).

Table.1 Salient characteristics of soils employed in experiment

\begin{tabular}{|c|c|c|c|}
\hline Soil properties & S-1 & S-2 & S-3 \\
\hline \multicolumn{4}{|l|}{ 1.Physical Properties } \\
\hline \multicolumn{4}{|l|}{ Mechanical composition } \\
\hline a) Sand (\%) & 55 & 50 & 50 \\
\hline b) Silt (\%) & 25 & 25 & 24 \\
\hline c) Clay (\%) & 20 & 25 & 26 \\
\hline d) Textural class & $\begin{array}{c}\text { Sandy clay } \\
\text { loam }\end{array}$ & $\begin{array}{c}\text { Sandy clay } \\
\text { loam }\end{array}$ & $\begin{array}{c}\text { Sandy clay } \\
\text { loam }\end{array}$ \\
\hline \multicolumn{4}{|l|}{ 2. Physico- Chemical Properties } \\
\hline a) $\mathrm{pH}$ & 7.82 & 7.74 & 7.68 \\
\hline b) $\mathrm{EC}\left(\mathrm{dS} \mathrm{\textrm {m } ^ { - 1 } )}\right.$ & 0.84 & 0.96 & 0.74 \\
\hline \multicolumn{4}{|l|}{ 3. Chemical Properties } \\
\hline a) Soil organic carbon (\%) & 0.54 & 0.58 & 0.51 \\
\hline b) Free Calcium Carbonate (\%) & 1.22 & 1.86 & 1.94 \\
\hline c) Available nitrogen $\left(\mathrm{kg} \mathrm{ha}^{-1}\right)$ & 182 & 188 & 188 \\
\hline d) Available phosphorus $\left(\operatorname{kg~}_{2} \mathrm{O}_{5} \mathrm{ha}^{-1}\right)$ & 69 & 82 & 107 \\
\hline e) Available potassium $\left(\mathrm{kg} \mathrm{K}_{2} \mathrm{O} \mathrm{ha}^{-1}\right)$ & 575 & 506 & 486 \\
\hline f) Available sulphur $\left(\mathrm{mg} \mathrm{kg}^{-1}\right)$ & 18.2 & 17.6 & 17.3 \\
\hline g) Available copper $\left(\mathrm{mg} \mathrm{kg}^{-1}\right)$ & 0.79 & 0.72 & 0.76 \\
\hline h) Available manganese (mg kg-1) & 3.88 & 3.91 & 4.15 \\
\hline i) Available iron $\left(\mathrm{m} \mathrm{kg}^{-1}\right)$ & 5.86 & 5.92 & 6.28 \\
\hline j) Available zinc ( $\mathrm{mg} \mathrm{kg}^{-1}$ ) & 0.78 & 0.75 & 0.72 \\
\hline
\end{tabular}


Table.2 Effect of different levels of $\mathrm{N}$ and $\mathrm{P}$ on seed yield (g pot-1) of soybean crop in high phosphorus soils

\begin{tabular}{|c|c|c|c|c|c|c|c|c|c|c|}
\hline \multicolumn{11}{|c|}{3 Factor Table } \\
\hline \multirow[t]{2}{*}{ N Levels } & \multicolumn{3}{|c|}{$\mathrm{S1}\left(69 \mathrm{~kg} \mathrm{P}_{2} \mathrm{O}_{5} \mathrm{ha}^{-1}\right)$} & \multicolumn{3}{|c|}{$\mathrm{S} 2\left(82 \mathrm{~kg} \mathrm{P}_{2} \mathrm{O}_{5} \mathrm{ha}^{-1}\right)$} & \multicolumn{3}{|c|}{ S3 (107 kg $\mathrm{P}_{2} \mathrm{O}_{5} \mathrm{ha}^{-1)}$} & \multirow{2}{*}{$\begin{array}{l}\text { Grand } \\
\text { Mean }\end{array}$} \\
\hline & $\begin{array}{c}\text { P1 } \\
\text { (70\% RDP) }\end{array}$ & $\begin{array}{c}\text { P2 } \\
(100 \% \text { RDP })\end{array}$ & Mean & $\begin{array}{c}\text { P1 } \\
\text { (70\% RDP) }\end{array}$ & $\begin{array}{c}\text { P2 } \\
(100 \% \text { RDP })\end{array}$ & Mean & $\begin{array}{c}\text { P1 } \\
\text { (70\% RDP) }\end{array}$ & $\begin{array}{c}\text { P2 } \\
(100 \% \text { RDP })\end{array}$ & Mean & \\
\hline $\begin{array}{l}\text { N1(60 kg } \\
\left.\text { N ha }^{-1}\right)\end{array}$ & 11.99 & 12.26 & 12.12 & 12.88 & 13.21 & 13.04 & 13.57 & 13.86 & 13.71 & 12.96 \\
\hline $\begin{array}{c}\text { N2 (80 kg } \\
\left.\text { N ha }^{-1}\right)\end{array}$ & 13.14 & 13.43 & 13.28 & 14.51 & 14.78 & 14.65 & 15.72 & 16.00 & 15.86 & 14.60 \\
\hline $\begin{array}{c}\text { N3 (100 } \\
\left.\operatorname{kg~N~ha~}^{-1}\right)\end{array}$ & 13.33 & 13.71 & 13.52 & 14.78 & 15.09 & 14.93 & 16.12 & 16.39 & 16.25 & 14.90 \\
\hline $\begin{array}{c}\text { N4 (120 } \\
\left.\operatorname{kg~N~ha~}^{-1}\right)\end{array}$ & 13.75 & 14.03 & 13.89 & 15.11 & 15.42 & 15.27 & 16.22 & 16.58 & 16.40 & 15.18 \\
\hline Mean & 13.05 & 13.35 & 13.20 & 14.32 & 14.62 & 14.47 & 15.40 & 15.71 & 15.56 & 14.41 \\
\hline
\end{tabular}

\begin{tabular}{|c|c|c|c|c|c|c|c|c|c|c|c|c|}
\hline \multicolumn{13}{|c|}{2 Factor Tables } \\
\hline Treatment & P1 & $\mathbf{P 2}$ & Mean & Treatment & S1 & S2 & S3 & Mean & Treatment & P1 & $\mathbf{P 2}$ & Mean \\
\hline N1 & 12.81 & 13.11 & 12.96 & N1 & 12.12 & 13.04 & 13.71 & 12.96 & S1 & 13.05 & 13.35 & 13.20 \\
\hline $\mathbf{N 2}$ & 14.46 & 14.74 & 14.60 & $\mathbf{N 2}$ & 13.28 & 14.65 & 15.86 & 14.60 & S2 & 14.32 & 14.62 & 14.47 \\
\hline N3 & 14.74 & 15.06 & 14.90 & N3 & 13.52 & 14.93 & 16.25 & 14.90 & S3 & 15.40 & 15.71 & 15.56 \\
\hline N4 & 15.03 & 15.34 & 15.18 & N4 & 13.89 & 15.27 & 16.40 & 15.18 & Mean & 14.25 & 14.56 & 14.41 \\
\hline Mean & 14.26 & 14.56 & 14.41 & Mean & 13.20 & 14.47 & 15.56 & 14.41 & & $\mathbf{S}$ & $\mathbf{P}$ & $\mathbf{S X} \mathbf{P}$ \\
\hline & $\mathbf{N}$ & $\mathbf{P}$ & N X P & & $\mathbf{N}$ & $\mathbf{S}$ & NXS & SEd \pm & 0.23 & - & 0.32 \\
\hline $\operatorname{SEd}( \pm)$ & 0.26 & - & 0.37 & \multicolumn{2}{|c|}{$\operatorname{SEd}( \pm)$} & 0.26 & 0.23 & 0.45 & $\begin{array}{c}\text { CD } \\
(P=0.05)\end{array}$ & 0.47 & NS & 0.67 \\
\hline $\begin{array}{c}\text { CD } \\
(P=0.05)\end{array}$ & 0.66 & NS & 0.77 & \multicolumn{2}{|c|}{$\mathrm{CD}(\mathrm{P}=0.05)$} & 0.66 & 0.47 & 0.94 & \multicolumn{2}{|c|}{$\begin{array}{c}\text { N X S X } \\
\text { P:SEd } \pm: 0.64\end{array}$} & \multicolumn{2}{|c|}{$\begin{array}{c}\text { CD } \\
(\mathbf{p}=\mathbf{0 . 0 5}): 1.33\end{array}$} \\
\hline
\end{tabular}


Table.3 Effect of different levels of $\mathrm{N}$ and $\mathrm{P}$ on haulm yield (g pot-1) of soybean crop in high phosphorus soils

\begin{tabular}{|c|c|c|c|c|c|c|c|c|c|c|}
\hline \multicolumn{11}{|c|}{3 Factor Table } \\
\hline \multirow[t]{2}{*}{ N Levels } & \multicolumn{3}{|c|}{$\mathrm{S1}\left(69 \mathrm{~kg} \mathrm{P}_{2} \mathrm{O}_{5} \mathrm{ha}^{-1}\right)$} & \multicolumn{3}{|c|}{$\mathrm{S} 2\left(82 \mathrm{~kg} \mathrm{P}_{2} \mathrm{O}_{5} \mathrm{ha}^{-1}\right)$} & \multicolumn{3}{|c|}{ S3 (107 kg $\left.\mathrm{P}_{2} \mathrm{O}_{5} \mathrm{ha}^{-1}\right)$} & \multirow{2}{*}{$\begin{array}{l}\text { Grand } \\
\text { Mean }\end{array}$} \\
\hline & $\begin{array}{c}\text { P1 } \\
\text { (70\% RDP) }\end{array}$ & $\begin{array}{c}\text { P2 } \\
\text { (100\% RDP) }\end{array}$ & Mean & $\begin{array}{c}\text { P1 } \\
\text { (70\% RDP) }\end{array}$ & $\begin{array}{c}\text { P2 } \\
\text { (100\% RDP) }\end{array}$ & Mean & $\begin{array}{c}\text { P1 } \\
\text { (70\% RDP) }\end{array}$ & $\begin{array}{c}\text { P2 } \\
\text { (100\% RDP) }\end{array}$ & Mean & \\
\hline N1(60 kg N ha $\left.{ }^{-1}\right)$ & 16.80 & 17.50 & 17.15 & 18.06 & 18.65 & 18.35 & 19.40 & 20.11 & 19.75 & 18.42 \\
\hline $\mathrm{N} 2\left(\begin{array}{c}80 \\
\mathbf{1}\end{array}\right)$ & 19.26 & 20.15 & 19.70 & 20.60 & 21.32 & 20.96 & 22.15 & 22.70 & 22.42 & 21.03 \\
\hline $\mathrm{N3}\left(\begin{array}{c}100 \\
\mathbf{k}^{\prime}\end{array}\right.$ & 20.23 & 20.90 & 20.56 & 21.47 & 22.25 & 21.86 & 22.85 & 23.72 & 23.29 & 21.90 \\
\hline N4 $\left(\begin{array}{c}120 \\
{ }_{1}\end{array}\right)$ & 20.59 & 21.24 & 20.92 & 21.89 & 22.59 & 22.24 & 23.29 & 24.59 & 23.94 & 22.37 \\
\hline Mean & 19.22 & 19.94 & 19.58 & 20.50 & 21.20 & 20.85 & 21.92 & 22.78 & 22.35 & 20.93 \\
\hline
\end{tabular}

2 Factor Tables

\begin{tabular}{|c|c|c|c|c|c|c|c|c|c|c|c|c|}
\hline \multicolumn{13}{|c|}{2 Factor Tables } \\
\hline Treatment & P1 & $\mathbf{P 2}$ & Mean & Treatment & S1 & S2 & S3 & Mean & Treatment & P1 & $\mathbf{P 2}$ & Mean \\
\hline N1 & 18.08 & 18.75 & 18.42 & N1 & 17.15 & 18.35 & 19.75 & 18.42 & S1 & 19.22 & 19.94 & 19.58 \\
\hline $\mathbf{N} 2$ & 20.67 & 21.39 & 21.03 & $\mathbf{N} 2$ & 19.70 & 20.96 & 22.42 & 21.03 & S2 & 20.50 & 21.20 & 20.85 \\
\hline N3 & 21.51 & 22.29 & 21.90 & N3 & 20.56 & 21.86 & 23.29 & 21.90 & S3 & 21.92 & 22.78 & 22.35 \\
\hline N4 & 21.92 & 22.81 & 22.37 & N4 & 20.92 & 22.24 & 23.94 & 22.37 & Mean & 20.54 & 21.30 & 20.93 \\
\hline Mean & 20.55 & 21.31 & 20.93 & Mean & 19.58 & 20.85 & 22.35 & 20.93 & & $\mathbf{S}$ & $\mathbf{P}$ & S X P \\
\hline & $\mathbf{N}$ & $\mathbf{P}$ & N X P & \multirow{2}{*}{\multicolumn{2}{|c|}{$\operatorname{SEd}( \pm)$}} & $\mathbf{N}$ & $\mathbf{S}$ & NXS & SEd \pm & 0.54 & - & 0.76 \\
\hline $\operatorname{SEd}( \pm)$ & 0.62 & - & 0.88 & & & 0.62 & 0.54 & 1.08 & $\begin{array}{c}\text { CD } \\
(\mathbf{P}=0.05)\end{array}$ & 1.11 & NS & 1.57 \\
\hline $\begin{array}{c}\text { CD } \\
(P=0.05)\end{array}$ & 1.55 & NS & 1.82 & \multicolumn{2}{|c|}{$\mathrm{CD}(\mathrm{P}=0.05)$} & 1.55 & 1.11 & 2.23 & \multicolumn{2}{|c|}{$\begin{array}{l}\text { N X SX P: } \\
\text { SEd } \pm: 1.52\end{array}$} & \multicolumn{2}{|c|}{$\begin{array}{c}\text { CD } \\
(\mathbf{p}=\mathbf{0 . 0 5}): 3.15\end{array}$} \\
\hline
\end{tabular}


Highest seed yield (15.56 $\mathrm{g} \mathrm{pot}^{-1}$ ) of soybean was observed in soil with native available $\mathrm{P}_{2} \mathrm{O}_{5}$ of $107 \mathrm{~kg} \quad \mathrm{P}_{2} \mathrm{O}_{5} \quad \mathrm{ha}^{-1}$ which is significantly higher by $7.53 \%$ (14.47g pot $\left.^{-1}\right)$ and $17.87 \%$ (13.20 $\left.\mathrm{g} \mathrm{pot}^{-1}\right)$ over seed yield recorded in soil with native available $\mathrm{P}_{2} \mathrm{O}_{5}$ of 82 and $69 \mathrm{~kg} \mathrm{P}_{2} \mathrm{O}_{5} \mathrm{ha}^{-1}$, respectively. As the native $\mathrm{P}$ fertility of soil was high there is possibility of more availability of $\mathrm{P}$ in soil solution which demands more nitrogen also for balanced nutrition might be the reason for higher yields in very high $\mathrm{P}$ soil.

Haulm yield of soybean also significantly influenced by application of different doses of $\mathrm{N}$ in high $\mathrm{P}$ soils (Table. 3). Application of $\mathrm{N} @ 80 \mathrm{~kg} \mathrm{~N} \mathrm{ha}{ }^{-1}$ increased the soybean haulm yield significantly by $14.16 \%$ over 60 $\mathrm{kg} \mathrm{N} \mathrm{ha}{ }^{-1}$. Further increase in dose of $\mathrm{N}$ from 80 to $120 \mathrm{~kg} \mathrm{~N} \mathrm{ha}^{-1}$ to soybean crop did not influence the haulm yield of soybean crop significantly in these high $\mathrm{P}$ soils. Increase in haulm yield in response to $\mathrm{N}$ application was also reported by Begum et al., (2015) and Yadravi and Angadi (2015). Application of different doses of phosphorus fertilizer to high $\mathrm{P}$ soils does not influenced significantly the haulm yield of soybean crop. It is noticed that the application of $70 \%$ RDP recorded on par haulm yield $\left(20.55 \mathrm{~g} \mathrm{pot}^{-1}\right)$ with that of $100 \%$ RDP (21.31 $\left.\mathrm{g} \mathrm{pot}^{-1}\right)$ in this high P soils. The increment in haulm yield due to $100 \%$ RDP was $3.69 \%$ with that of $70 \%$ RDP. These observations clearly indicate that it is possible to reduce current RDP by $30 \%$ in high $\mathrm{P}$ soils. Improvement in haulm yields depending upon initial available phosphorus status was reported by Kakad et al., (2008) and Dhage et al., (2014). The combination of $\mathrm{N} 100 \mathrm{~kg} \mathrm{~N} \mathrm{ha}{ }^{-1}$ in conjunction with 70 or $100 \%$ RDP to soybean crop results in highest haulm yield in high P soils. Increase in haulm yields with increase in doses of $\mathrm{N}$ and $\mathrm{P}$ was also reported by Patel and Chandravanshi (1996), Begum et al., (2015) and Raghuveer et al., (2017).
High P soils having different native available phosphorus status also significantly affected the haulm yield of soybean (Table.3). Highest haulm yield (22.35 $\mathrm{g} \mathrm{pot}^{-1}$ ) of soybean was observed in soil with native available $\mathrm{P}_{2} \mathrm{O}_{5}$ of $107 \mathrm{~kg} \mathrm{P}_{2} \mathrm{O}_{5}$ ha $^{-1}$ which is significantly higher by $6.71 \%\left(20.85 \mathrm{~g} \mathrm{pot}^{-1}\right)$ and $12.39 \%(19.58 \mathrm{~g}$ pot $^{-1}$ ) over soils with native available $\mathrm{P}_{2} \mathrm{O}_{5}$ of 82 and $69 \mathrm{~kg} \mathrm{P}_{2} \mathrm{O}_{5} \mathrm{ha}^{-1}$, respectively. In general the combination of high $\mathrm{N}$ doses like 100 or $120 \mathrm{~kg} \mathrm{~N} \mathrm{ha}^{-1}$ in very high $\mathrm{P}$ soil $\left(107 \mathrm{kgP}_{2} \mathrm{O}_{5} \mathrm{ha}^{-1}\right)$ recorded highest haulm yields when compared to other combinations.

The experiment revealed that significant increasing in the seed yield of soybean from 12.96 to $14.60 \mathrm{~g} \mathrm{pot}^{-1}(12.7 \%)$ was found with increase in application of $\mathrm{N}$ from 60 to $80 \mathrm{~kg}$ $\mathrm{N}$ ha $^{-1}$. Application of $\mathrm{P}$ fertilizer to soybean crop in high $\mathrm{P}$ soils at the rate of $100 \%$ RDP $\left(60 \mathrm{~kg} \mathrm{P}_{2} \mathrm{O}_{5} \mathrm{ha}^{-1}\right)$ or $70 \%$ RDP $\left(42 \mathrm{~kg} \mathrm{P}_{2} \mathrm{O}_{5}\right.$ $\mathrm{ha}^{-1}$ ) were found to be statistically on par (14.56 and $14.26 \mathrm{~g} \mathrm{pot}^{-1}$ ) with each other. The soil with native available $\mathrm{P}_{2} \mathrm{O}_{5}$ of $107 \mathrm{~kg} \mathrm{P}_{2} \mathrm{O}_{5}$ $\mathrm{ha}^{-1}$ (S3) resulted in highest seed yield of $15.56 \mathrm{~g} \mathrm{pot}^{-1}$ followed by soil with 82 (14.47 $\mathrm{g} \mathrm{pot}^{-1}$ ) and $69 \mathrm{~kg} \mathrm{P}_{2} \mathrm{O}_{5} \mathrm{ha}^{-1}$ (13.29 $\mathrm{g} \mathrm{pot}^{-}$ $\left.{ }^{1}\right)$.Similar trend was observed increase of haulm yield of soybean. Thus, application of $80 \mathrm{~kg} \mathrm{~N} \mathrm{ha}^{-1}$ with $70 \%$ RDP recorded highest yield and is the better combination to obtain maximum yields of soybean in high $\mathrm{P}$ soils.

\section{References}

Abdalmohsin, R.K. 2016. Effect of biofertilizer, nitrogen, and phosphorus on irrigated soybean (Glycine max) in Gezira-Sudan. Journal of Agricultural and Biological Science. 11(9): 351-359.

Akhtar, N., Amjad, M and Anjum, A.M. 2003. Growth and yield response of Pea (Pisum sativum L.) crop to phosphorous and potassium application. Pakistan Journal of Agricultural Sciences. 40: 3-4.

Babu, S.P., Reddy, V and Sathe, S.A. 2005. Phosphorus requirement and use 
efficiency by sunflower, Helianthus annus L. in $\mathrm{P}$ - accumulated Vertisols. Oil seeds Research. 22 (2): 410 - 413.

Barik, K.C., and Chandel, A.S. 2001. Effect of copper fertilization on plant growth, seed yield, copper and phosphorus uptake in soybean (Glycine max) and their residual availability in Mollisol. Indian Journal of Agronomy. 46(2): 319-326.

Begum, A., Islam, A., Ahmed, Q.M., Islam, M.A and Rahman, M.M. 2015. Effect of nitrogen and phosphorus on the growth and yield performance of soybean. Research in Agricultural, Livestock and Fisheries. 2(1): 35-42.

DES, 2017.

http://data.gov.in/catalogs/...department/d irectorate-economics- and- statistics des

Dhage, S. J., Patil, V. D and Dhamak, A. L. 2014. Influence of phosphorus and sulphur levels on nodulation, growth parameters and yield of soybean (Glycine max) grown on Vertisol. Asian Journal of Soil Science. 9 (2): 244-249.

Ikeogu, U. N and Nwofia, G. E. 2013. Yield parameters and stabilty of soybean [Glycine max (L.) merril] as influenced by phosphorus fertilizer rates in two ultisols. Journal of Plant Breeding and Crop Science. 5(4): 54-63.

Kakad, G.J., Tawar, R.V., Hage, N.D., Ingle, M.B and Fathepurkar, S.C. 2008. Effect of zinc and phosphorus on yield and quality parameters of soybean. International Journal of Plant Sciences. 3 (2): 355-356.

Patel, S. R. and Chandravanshi, B. R. 1996. Nitrogen and phosphorus nutrition of soybean (Glycine max) grown in Vertisol. Indian Journal of Agronomy. 41 (4): 601-603.
Raghuveer, Hosmath, J.A., Keerti and Chandranath, H.T. 2017. Effect of different levels of nitrogen and phosphorus on growth and yield parameter of soybean (Glycine max L. Merrill). International Journal for Pure and Applied Bioscience. 5(4): 1686-1690.

Ramya, V. S., Madhavi, A., Babu, P. S and Madhavi, K. 2015. Zinc requirement to rice in high $\mathrm{P}$ soil with sufficient zinc status. The Journal of research PJTSAU. 43 (3): 33 - 35.

Siddiqui, M. H., Oad, F. C., Kumbhar, A. M and Buriro, U. A. 2007. NP requirement of soybean varieties for yield and yield components. Journal of Agronomy. 6 (1): 222- 224.

Srinivas, A., Babu, P. S., Madhavi, A., Vidyasagar, G. E. C. H and Shankar, G.M. 2017. Multi-location assessment of variability and relationships of phosphorus fixation, fractions, availability and recovery under high $\mathrm{P}$ Alfisols. Indian Journal of Soil Conservation. 45 (3): 308 - 317.

Varavipour, M., Hasan, R and Singh, D. 1999. Effect of applied phosphorus sulphur and zinc on yield and uptake parameters of wheat (Triticum aestivum) and soybean (Glycine max) grown on a loamy sand. Indian Journal of Agricultural Sciences. 69 (1): 1-4.

www.sopa.org. 2017.

Yadravi, M and Angadi, V.V. 2015. Effect of time and method of application of varied levels of nitrogen in soybean. M.Sc ( $\mathrm{Ag}$.) Thesis. University of Agricultural Science, Dharwad, Karnataka, India.

\section{How to cite this article:}

Jagadesh M., A. Madhavi, M. Chandini Patnaik and Madhavi Lata A. 2020. Nitrogen and Phosphorus Requirement to Soybean in High Phosphorus Soils. Int.J.Curr.Microbiol.App.Sci. 9(06): 4202-4209. doi: https://doi.org/10.20546/ijcmas.2020.906.492 